\title{
Design, Synthesis and Structural Inspection of Some Novel Di- And Tri-Azomethene Compounds as Chemo Sensors for the Detection of Various Metal Ions
}

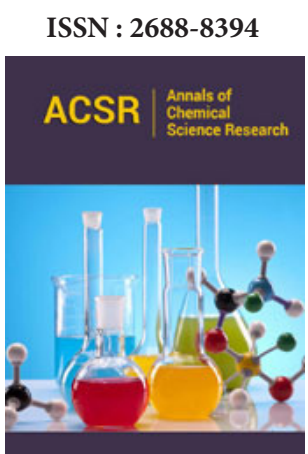

*Corresponding author: Abu-Dief AM, Chemistry Department, Egypt

Submission: 此 July 1, 2019

Published: 侮 August 22, 2019

Volume 1 - Issue 4

How to cite this article: Abdel-Rahman L, Abu-Dief A, Abdel-Mawgoud A. Design, Synthesis and Structural Inspection of Some Novel Di- And Tri-Azomethene Compounds as Chemo Sensors for the Detection of Various Metal Ions. Ann Chem Sci Res. 1(4).ACSR.000518.2019. DOI: 10.31031/ACSR.2019.01.000518

Copyright@ Abu-Dief AM, This article is distributed under the terms of the Creative Commons Attribution 4.0 International License, which permits unrestricted use and redistribution provided that the original author and source are credited.
Abdel-Rahman LH, Abu-Dief AM* and Abdel-Mawgoud AAH

Chemistry Department, Egypt

\begin{abstract}
In this study, NBA imine compound was synthesized via an easy one-pot condensation of 3-nitro-benzaldyhide with 2-amino benzoic acid in 1:1 ratio and DAPH imine compound derived from 2,6-diacetyl pyridine and phenyl hydrazine hydrochloride. Consequences of the newly synthesized compounds hooked up with the aid of FT-IR, elemental analyses, 13C-NMR ,1H-NMR and digital spectral research. Experiments had been consistent with their chemical structures. Theoretical DFT calculations had been implemented to confirm the molecular geometry of the investigated chemo-sensors. The sensor property of all organized imines had been tested upon addition of the metal ions, consisting of $\mathrm{Cr}$ (III), Fe(II), Co(II), $\mathrm{Ni}(\mathrm{II}), \mathrm{Cu}(\mathrm{II}), \mathrm{Zn}(\mathrm{II}), \mathrm{Mn}(\mathrm{II}), \mathrm{VO}(\mathrm{II})$ and Pd(II)). The interactions among receptors and ions are effortlessly monitored with the aid of UV-visible spectroscopy. DAPH receptor confirmed color modification from blood red to excessive deep green color to $\mathrm{Co}(\mathrm{II})$, a yellow color to $\mathrm{Cu}(\mathrm{II})$ and different colors to different ions. Where the NBA receptor showed color modification from light yellow to excessive deep orange color to $\mathrm{Fe}(\mathrm{II})$, pale orange to $\mathrm{Pd}(\mathrm{II})$ and different colors for other ions.
\end{abstract}

Keywords: Azomethine; Chemo-sensors; DFT calculations; Solvent effect; Spectroscopic titration; Receptor.

\section{Introduction}

Synthesis and designing of recent imine compounds with chemo-sensor or colorimetric, that is non-dangerous, eco-friendly and particularly sensitive and selective toward metals, are presently of splendid interest. Many natural sensors had been advanced to find out

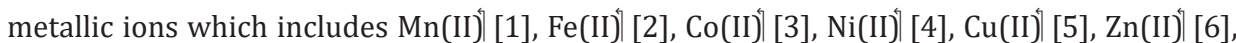
$\mathrm{Mn}(\mathrm{II}))^{\text {[ [7] }} \mathrm{VO}(\mathrm{II})$ [ [8], and Pd(II)] [9] in aqueous media. Imine compounds which having an azomethine group $(-\mathrm{C}=\mathrm{N}-)$, are many of the maximum essential ligands utilized in modernday coordination chemistry because of their well-known coordinative functionality [10-18]. Those imines and their metal imine chelates have extensive utility in exceptional regions of electrochemistry [19], catalysis [20,21], solid phase extraction of metallic ions and separation routs [22], and several kinds of polymerization [23]. They're additionally discovered to showcase a huge variety of organic activities, which have been containing antibacterial [24], antifungal [25], antimalarial [26], antiproliferative [27], anti-inflammatory [28], antiviral [29], antitumor [30,31] and antioxidant [32]. Furthermore, they may be turning into essential inside the corrosion inhibitors [33], extremely selective polymer membrane electrodes [34], optical sensors [35], and biological probes [36]. Different imines are organized by way of the condensation reaction of prime amines with vivacious carbonyl gatherings of aldehydes in one: one M proportion. on this work, it's been intended to procure new colorimetric chemosensors for particular recognition of $\mathrm{Cr}(\mathrm{III})$, Fe(II), Co(II), Ni(II), Cu(II), $\mathrm{Zn}(\mathrm{II}), \mathrm{Mn}(\mathrm{II}), \mathrm{VO}(\mathrm{II})$ and Pd(II)| particles in aqueous media. Therefore, NBA imine containing nitro group, became prepared via an easy one-pot condensation of 3-nitro-benzaldyhide with 2-amino benzoic acid in 1:1 ratio, respectively while DAPH tri-imine- was synthesized by condensation of 2,6 -diacetyl-pyridine with phenyl-hydrazinium chloride, respectively. So, a new novel imine, that have greater binding nature toward metallic ions, had been synthesized as chemo-sensors. 


\section{Experimental}

\section{Materials and reagents}

Every one of the reagents and solvents utilized in the preparation of compounds have been of commercially to be had accessible reagent grade and applied without purification. They covered 3-nitro benzaldehyde, 2-amion benzoic acid, 2, 6 diacetylpyridine, phenyl-hydrazinium chloride, vanadyl acetylacetonate $\left(\mathrm{VO}\left(\mathrm{C}_{5} \mathrm{H}_{7} \mathrm{O}_{2}\right)_{2}\right)$, chromium nitrate $\left(\mathrm{Cr}(\mathrm{NO} 3) 3.9 \mathrm{H}_{2} \mathrm{O}\right)$, copper chloride $\left(\mathrm{CuCl}_{2} \cdot 2 \mathrm{H}_{2} \mathrm{O}\right)$, cobalt chloride $\left(\mathrm{CoCl}_{2} \cdot 6 \mathrm{H}_{2} \mathrm{O}\right)$, nickel nitrate hexa-hydrate $\left(\mathrm{Ni}\left(\mathrm{NO}_{3}\right)_{2} \cdot 6 \mathrm{H}_{2} \mathrm{O}\right)$, zinc nitrate hexa-hydrate $\left(\mathrm{Zn}\left(\mathrm{NO}_{3}\right)_{2} \cdot 6 \mathrm{H}_{2} \mathrm{O}\right)$, manganese chloride $\left(\mathrm{MnCl}_{2} \cdot 4 \mathrm{H}_{2} \mathrm{O}\right)$, Ammonium ferrous sulfate $\left(\left(\mathrm{NH}_{4}\right) 2 \mathrm{Fe}\left(\mathrm{SO}_{4}\right)_{2} \cdot 6 \mathrm{H}_{2} \mathrm{O}\right)$ and palladium acetate $(\mathrm{Pd}(\mathrm{OAc}) 2)$ had been acquired from Sigma-Aldrich. Spectroscopic grade ethanol, dimethyl formamide (DMF), toluene, methanol, chloroform, ammonium hydroxide and acetic acid products were used.

\section{Instrumentation}

Melting point to DAPH imine compound had been done on a melting point tool, Gallenkamp, UK. Infrared spectra have been registered as $\mathrm{KBr}$ pellets utilizing Shimadzu. FT-IR-8300 spectrophotometer. $1 \mathrm{H}$ and 13C NMR spectra have been acquired in DMSO-d6 solutions with a Bruker Avance DPX-500 spectrometer. All the scanning UV-Vis spectra in DMF have been recorded utilizing $10 \mathrm{~mm}$ matched quartz cells via PG spectrophotometer version $\mathrm{T}+80$. Elemental analyses which have been made at principal lab of Cairo University via Elemental analyzer Perkin-Elmer (model240c).

\section{Preparation of DAPH compound}

Five m mole $(0.82 \mathrm{~g})$ of 2,6 diacetyl-pyridine had been dissolved in ethanol and added dropwise to the ethanolic solution of five $\mathrm{m}$ mole $(0.545 \mathrm{~g})$ of phenyl-hydrazinium chloride on cold. Then, the resultant blood red precipitate was formed after half an hour from stirring. The solid product had been accumulated through suction filtered and had been washed by ethanol and dried over anhydrous $\mathrm{CaCl}_{2}$. Finally, pure blood red solid was afforded after all the precipitates drying for $12 \mathrm{~h}$ in vacuo at $55^{\circ} \mathrm{C}$. The yield was $95 \%$ and melting point is $210^{\circ} \mathrm{C}$.

$$
\begin{aligned}
& \text { FT-IR (KBr disc cm-1) (DAPH): } 1599 v(-\mathrm{CH}=\mathrm{N}) ; 3388 v\left(\mathrm{H}_{2} \mathrm{O}\right) ; \\
& 3265 v(-\mathrm{NH}-) ; 3093 v(-\mathrm{CH}-) ; 1536 v p y(-\mathrm{C}=\mathrm{N}) . \\
& \text { 1HNMR ( } \delta, \mathrm{ppm}) \text {, in DMSO-d6: } 9.9-9.4(\mathrm{br}, 2 \mathrm{H}, 2 \mathrm{NH}), 8.0- \\
& 6.86\left(\mathrm{~m}, 13 \mathrm{H} \text {, aromatic), } 2.44\left(\mathrm{~s}, 6 \mathrm{H}, 2 \mathrm{CH}_{3}\right) .\right.
\end{aligned}
$$

13CNMR ( $\delta$, ppm), in DMSO-d6: 145,129,120,118,113,12.

Elemental analysis (DAPH (C21H21N5)): carbon (found 73.39 $\%$, calc. 73.47\%); Hydrogen (found $6.09 \%$, calc. 6.12\%); Nitrogen (found $20.43 \%$, calc. $20.41 \%$ ).

\section{Preparation of NBA imine compound}

Five m mole $(0.69 \mathrm{~g})$ of antharanilic acid had been dissolved in ethanol and added dropwise to solution of ethanol of five $\mathrm{m}$ mole $(0.76 \mathrm{~g})$ of 3 -nitrobenzaldehyde on cold. Then the mixture was refluxed for five hours at $85{ }^{\circ} \mathrm{C}$. Then, the resultant pale-yellow precipitate had been formed. Solid product had been accumulated through suction filtered and had been washed by ethanol and dried over anhydrous $\mathrm{CaCl}_{2}$. Finally, pure yellow solid was afforded after all the precipitates drying for $12 \mathrm{~h}$ in vacuo at $55^{\circ} \mathrm{C}$. The yield was $83 \%$ and melting point is $215^{\circ} \mathrm{C}$.

FT IR (KBr disc cm-1) (NBA): $1626 v(-\mathrm{C}=\mathrm{N}) ; 3071 v(-\mathrm{CH}-)$; $3473 v(\mathrm{H} 2 \mathrm{O})$.

1HNMR ( $\delta$, ppm), in DMSO-d6: 10.16 (s,1H, COOH), 8.69 (s,1H, $\mathrm{CH}=\mathrm{N}), 6.51-8.48(\mathrm{~m}, 8 \mathrm{H}$, aromatic).

13CNMR ( $\delta, p p m)$, in DMSO-d6: 92,170,139,138.137,136,133, $132,131,130,121,120,115,114$.

Elemental analysis (NBA $\left(\mathrm{C} 14 \mathrm{H} 10 \mathrm{~N}_{2} \mathrm{O}_{4}\right)$ ): carbon (found 62.13 $\%$, calc. $62.18 \%$ ); Hydrogen (found $3.68 \%$, calc. $3.70 \%$ ); Nitrogen (found $10.37 \%$, calc. $10.36 \%$ ).

\section{Computational techniques to affirmation the suggested structures of the investigated chemo-sensors}

The lowest energy geometries were calculated, applying density functional theory and using the Gaussian09 program. The DFT/B3LYP/LANL2DZ level of theory was used for the geometry optimization to get the lowest energy structures for the prepared imine ligands [37].

\section{Absorption measurements of the prepared imine compounds}

UV- vis spectra had been estimated in DMF to (DHAP and NBA), and in different solvents (toluene, methanol and chloroform) with $0.01 \mathrm{mM}$ concentration over the wavelength extent $200-800 \mathrm{~nm}$ at room temperature. Changes in the wavelength of the maximum absorption $(\Lambda \max )$ had been additionally checked in pure solvents, basic and acidic media. $0.1 \mathrm{~mL} \mathrm{CH} 3 \mathrm{COOH}$ acid and $0.1 \mathrm{~mL} \mathrm{NH}_{4} \mathrm{OH}$ had been added up to the solutions $(5 \mathrm{~mL})$ in all non-polar and polar solvents to outfit the acidic and basic media, respectively.

\section{Colorimetric chemosensor}

Assessment of affectability: To research the detecting properties of the prepared DHAP and BNA imine compounds with various metal ions such as $\left(\mathrm{Cr}^{3+}, \mathrm{Fe}^{2+}, \mathrm{Vo}^{2+}, \mathrm{Co}^{2+}, \mathrm{Ni}^{2+}, \mathrm{Cu}^{2+}\right.$, $\mathrm{Zn}^{2+}$ and $\mathrm{Pd}^{2+}$ ) for complexation with receptor had been utilized. An inventory solution of the metal ions $(0.1 \mathrm{M})$ had been prepared in refined water, and it end up weakened to $0.1 \mathrm{mM}$ in water. An inventory solution of receptors $(0.1 \mathrm{mM})$ had been prepared in DMF. In selectivity analyzes, the check samples have been set up by method for putting two $\mathrm{mL}$ of metal cation solution $(0.1 \mathrm{mM})$ into $2 \mathrm{~mL}$ solution $(0.1 \mathrm{mM})$ of ligand. After blending them, UVvis spectra have been taken at room temperature within the wavelength interval of $200-800 \mathrm{~nm}$, in steps of one $\mathrm{nm}$ utilizing a 1-cm-thick quartz cell. For evaluation of the impact of time on the stableness of imines and the interplay of them with ions, UV-vis spectra had been also registered four days later.

UV-vis titration of the prepared imines with different metal ions: In titration experiments, on every occasion an one ml DMF solution of receptor $(0.1 \mathrm{mM})$ become filled in check tube, after 
which increasing volumes (0.1-1.00 ml) of aqueous solution of the metal ion $(0.1 \mathrm{M})$ have been added into tube. After blending those samples, UV-vis spectra have been taken at room temperature within wavelength interval of 200-800 nm.

Movement plot estimations: On this examination, the entire concentration $(0.1 \mathrm{M})$ and overall quantity (two $\mathrm{mL}$ ) of the receptor and metal ion have been put away steady and changing over the molar proportion of receptor from 0.1 to 1.0.

\section{Results and Discussion}

\section{Physicochemical properties of the investigated DAPH and NBA imine ligands}

Condensation of 2,6-diacetylpyridine with Phenyl hydrazine hydrochloride gave tri-dentate DHAP imine with red blood color, that aldehydes had been used at one: two $\mathrm{M}$ ratio. For NBA imine, a yellow precipitate was formed with the condensation of antharanilic acid and 3-nitrobenzaldyhede in 1:1M ratio. The newly synthesized tri-dentate DHAP imine with NNN donor atoms and bi-dentate NBA imine with NO benefactor atoms are steady at pressure and climatic temperature. They have been displayed phenomenal dissolvability in natural solvents like DMF. What's more they display dissolvability in methanol, ethanol, and acetone at low focuses. The analytical information is provided in experimental section, show excellent concurrences with the suggested structure of all prepared imines (Figure 1). Binding properties of DHAP and NBA imines towards chose metal particles $\mathrm{Cr}^{3+}, \mathrm{Fe}^{2+}, \mathrm{Vo}^{2+}, \mathrm{Co}^{2+}, \mathrm{Ni}^{2+}, \mathrm{Cu}^{2+}, \mathrm{Zn}^{2+}$ and $\mathrm{Pd}^{2+}$ ) had been assessed via colorimetry and UV-vis assimilation spectrophotometry at $25{ }^{\circ} \mathrm{C}$ in DMF-water blend.

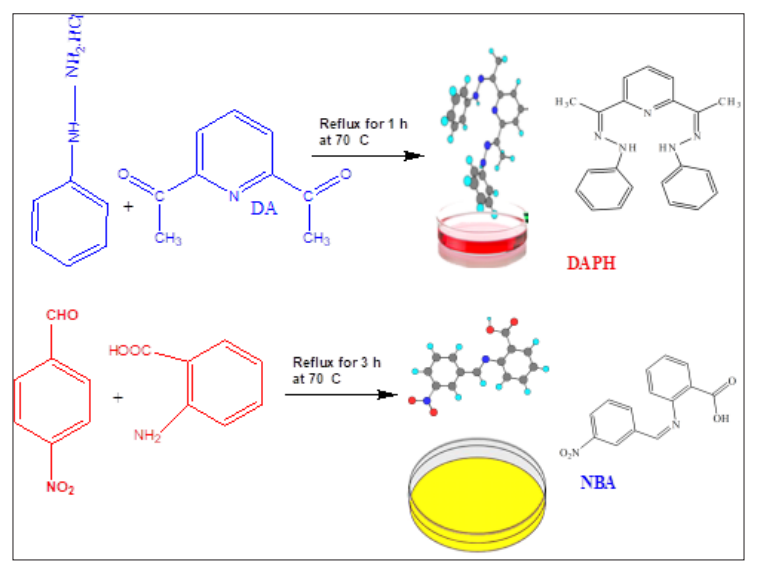

Figure 1: Schematic diagram for synthesis of the investigated chemosensors.

\section{Infrared spectra}

IR technique is used for representing the spectra of ligands. The prominent peak assignments are listed in experimental section and Figure 2,3. Bands due to $-\mathrm{CH}=\mathrm{N}$ is discernable and offer verification with respect to the structure of the ligand. A band observed at $1599 \mathrm{~cm}^{-1}$ in the DAPH ligand which corresponds to the $-\mathrm{CH}=\mathrm{N}$ stretching vibration. Band at $3388 \mathrm{~cm}^{-1}$ observed in the ligand spectrum is due to stretching vibrations of free $\mathrm{H}_{2} \mathrm{O}$. Band at $3265 \mathrm{~cm}^{-1}$ observed in the ligand spectrum is due to stretching vibrations of $-\mathrm{NH}-$ and band at $1536 \mathrm{~cm}^{-1}$ is due to stretching vibrations of $-\mathrm{CH}=\mathrm{N}$ of pyridine ring. But the ligand NBA showed band at $1626 \mathrm{~cm}^{-1}$, which corresponds to the $-\mathrm{CH}=\mathrm{N}$ stretching vibration $[38,39]$, band at $3473 \mathrm{~cm}^{-1}$ is due to stretching vibrations of free $\mathrm{H}_{2} \mathrm{O}$ and band at $3071 \mathrm{~cm}^{-1}$, which corresponds to the $-\mathrm{CH}$ aromatic stretching vibration.

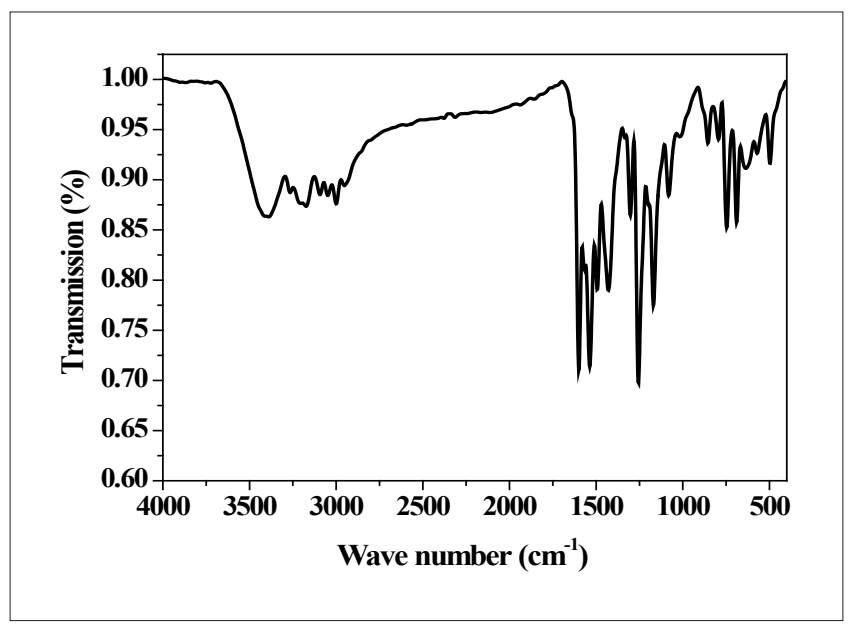

Figure 2: FT-IR spectrum of DAPH ligand. 


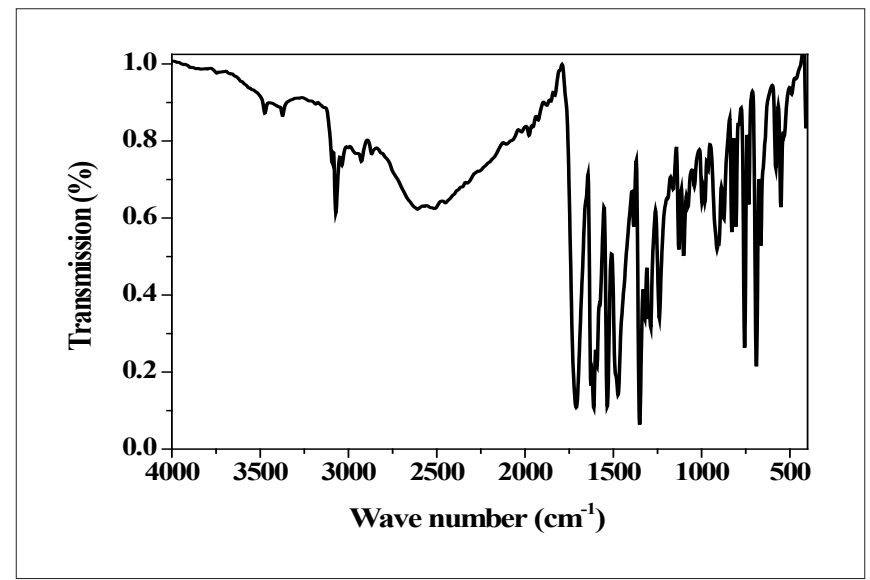

Figure 3: FT-IR spectrum of NBA ligand.

1H-NMR and13C-NMR spectra of the prepared DAPH imine ligand: To investigate the encapsulation behavior, $1 \mathrm{H}$ NMR and 13CNMR studies are used for demonstrating the interaction of the host molecule and guest molecule between DA and PH. The 1H NMR and13C-NMR results are shown in Figure 4,5 and experimental section. The 1HNMR spectrum of DAPH imine ligand had been displayed two broad signals at $\delta=9.90$ and $9.40 \mathrm{ppm}$, that have been referred to the two protons of - $\mathrm{NH}$ - group. Also it has been showed singlet signal at $\delta=2.44$ that had been assigned to the two methyl group. Moreover, it shows multiple signals at 8.00-6.86ppm for aromatic of 13- $\mathrm{CH}$ protons.13CNMR of DAPH imine ligand exhibited signal at $145.62 \mathrm{ppm}$ may be assigned to two azomethine carbon $[40,41]$. It exhibits signal at $12 \mathrm{ppm}$ which may be assigned to two symmetrical methyl carbons. The signals observed in the region 113.95-129.46ppm had been assigned to phenyl and pyridine ring carbons.

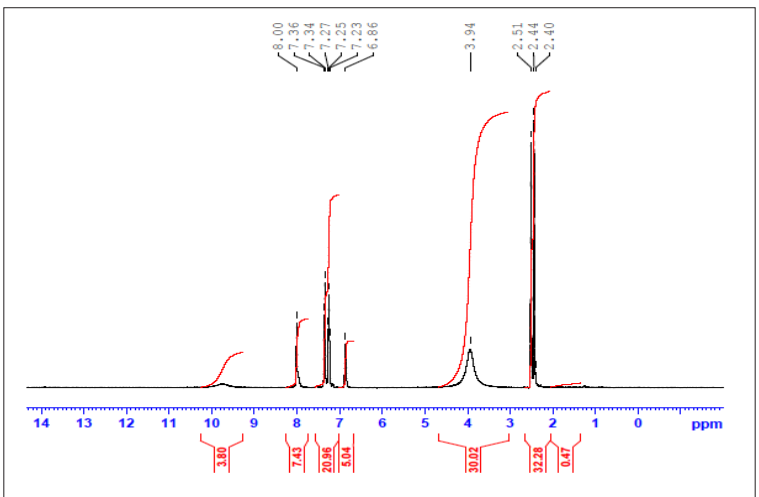

Figure 4: $1 \mathrm{H}$ NMR spectrum of DAPH imine ligand.

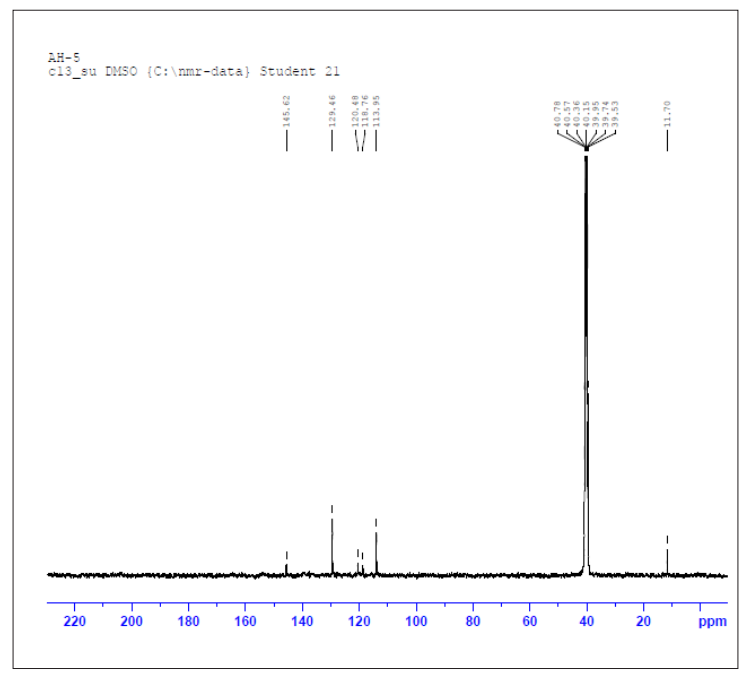

Figure 5: ${ }^{13} \mathrm{CNMR}$ spectrum of DAPH imine ligand. 
1H-NMR and 13C-NMR spectra of the prepared NBA imine ligand: To investigate the encapsulation behavior, $1 \mathrm{H}$ NMR and 13CNMR studies are used for demonstrating the interaction of the host molecule and guest molecule between NB and A. The $1 \mathrm{H} \mathrm{NMR}$ and13C-NMR results are shown in Figure 6,7 and experimental section. The 1HNMR spectrum of NBA imine ligand showed one singlet signal at $\delta=10.16 \mathrm{ppm}$, that is assigned to the one proton of carboxylic group. Also, it has been showed singlet signal at $\delta=8.69$ that had been assigned to the one proton of azomethine group. Moreover, it shows multiple t signals at 8.48-6.51ppm for aromatic of 8- CH protons.13C NMR of NBA imine ligand exhibited signal at $170.00 \mathrm{ppm}$ may be assigned to azomethine carbon [40,41]. It also exhibits signal at $192 \mathrm{ppm}$ which may be assigned to carboxylic carbon. The signals observed in the region 114-139ppm had been referred to phenyl carbons.

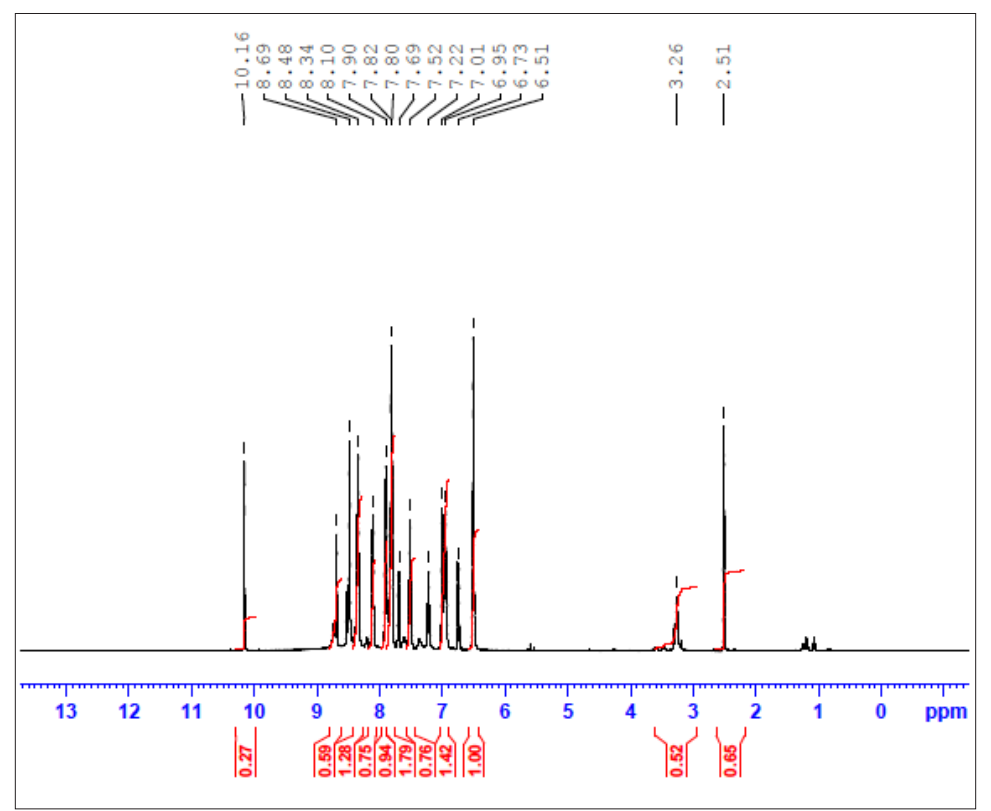

Figure 6: 1H NMR spectrum of NBA imine ligand.

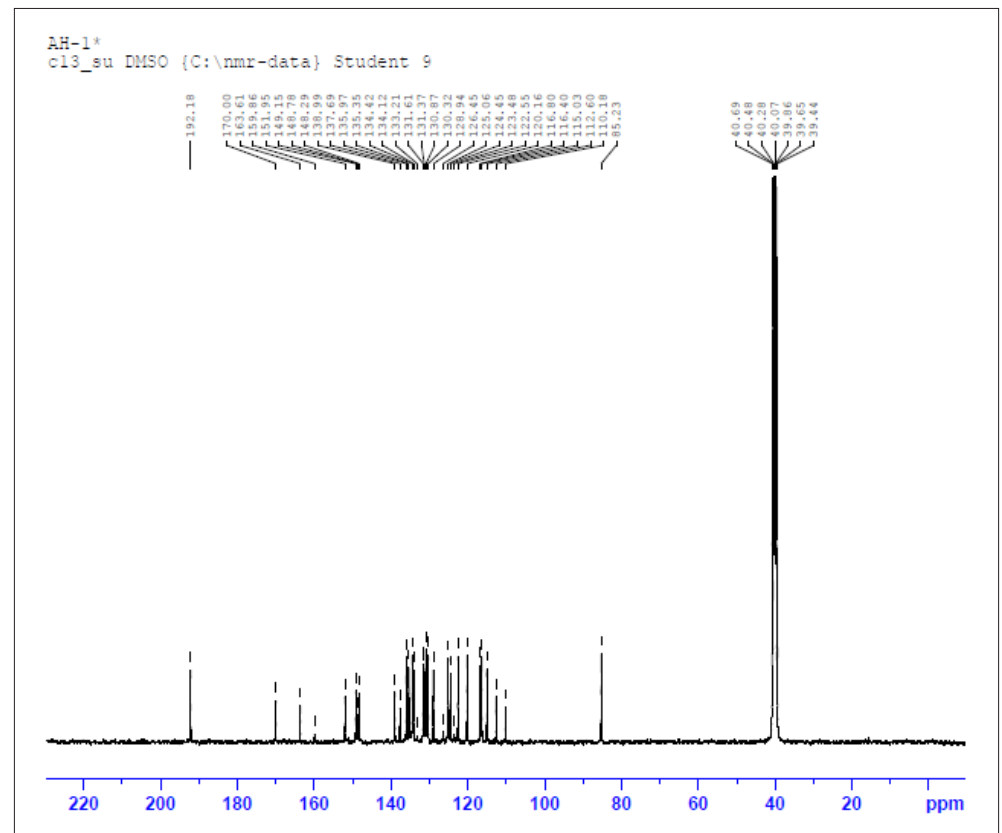

Figure 7: $13 \mathrm{CNMR}$ spectrum of NBA imine ligand.

\section{DFT calculations for the prepared imine compounds}

Figure 8 shows the optimized structures of the prepared imines as the lowest energy configurations and the normal charges on the atoms of, which indicates large electron density in nitrogen and oxygen atoms. The computed total energy, the highest occupied molecular orbital (HOMO) energies, the lowest unoccupied molecular orbital (LUMO) energies and the dipole moment for the investigated chemo-sensors ligands were calculated (Table1). 


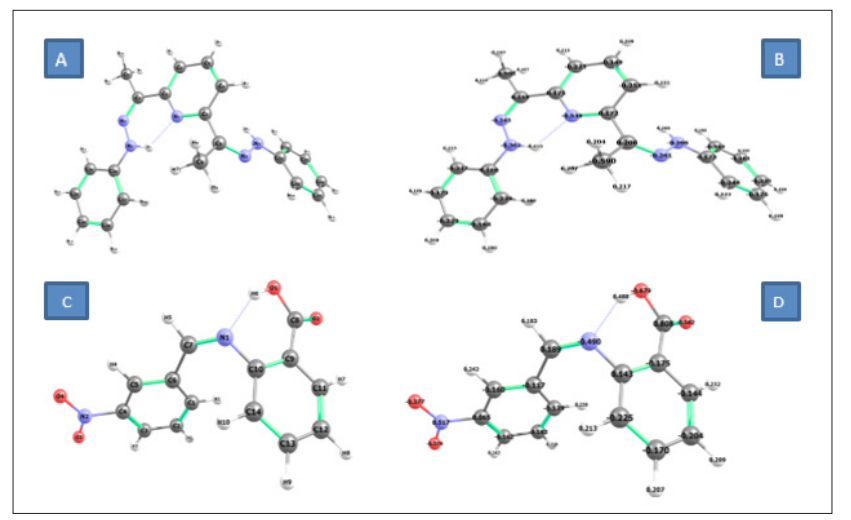

Figure 8: The optimized structures for the prepared (A), (B) DAPH and (C), (D) NBA imine chemosensors.

Table 1: Calculated energies of the prepared chemosensors at B3LYP/LANL2DZ.

\begin{tabular}{|c|c|c|c|c|c|}
\hline & $\mathbf{E}^{\mathbf{a}}$ & HOMO $^{\mathbf{b}}$ & $\mathbf{L U M O}^{\mathbf{c}}$ & $\boldsymbol{\Delta E}^{\mathbf{d}}$ & $\begin{array}{c}\text { Dipole } \\
\text { Momente }\end{array}$ \\
\hline DAPH & -1086.86 & -0.1967 & -0.0698 & 0.1269 & 3.378 \\
\hline NBA & -950.058 & -0.2588 & -0.1179 & 0.1409 & 4.439 \\
\hline
\end{tabular}

${ }^{\mathrm{a} E}$ : The total energy (a.u.). ${ }^{\mathrm{b}} \mathrm{HOMO}$ : Highest Occupied Molecular Orbital (eV).

'LUMO: Lowest Unoccupied Molecular Orbital (eV).

${ }^{\mathrm{d}} \Delta \mathrm{E}: \mathrm{E}_{\text {LUMO }}-\mathrm{E}_{\text {Hомо }}(\mathrm{eV})$. ${ }^{\mathrm{e}}$ Dipole moment (Debye).

\section{UV-vis spectra of the prepared imine compounds in different mediums}

The absorption spectra of the prepared imines were measured in solvents of different polarities such as DMF, Methanol, and chloroform and toluene solution. The spectral information has been given in Table 2. DAPH imine compound shows absorption maxima until 534nm whereas NBA imine compound had not shown any assimilation maxima above 400nm (Figure 9, 10). This could be attributed to the nature structure of each one of them and the interaction between different solvents and each compound depending on $\mathrm{pH}$ of the medium. The absorption bands in region around $360 \mathrm{~nm}$ observed in spectra of DAPH and NBA imines had been assigned to the $n-\pi *$ transition of imine chromophores. In polar solvents such as methanol and DMF, DHAP imine compound shows band at 520 and 534, respectively whereas these bands disappear while moving to nonpolar toluene solvent. This could mainly ascribe to the stability of these bands in polar solvent which have $n-\pi^{*}$ or $n-\sigma^{*}$ transitions as the polarity of the investigated solvents follow the order of: methanol $>\mathrm{DMF}>\mathrm{CHCl}_{3}>$ Toluene. In acidic medium, the two imine bonds of DAPH compound are protonated and blocked. Thus, bands at 520 and 534 methanol and DMF, respectively are disappeared. In basic medium, there is an intermolecular hydrogen bond formed between hydroxide ion of basic medium and -NH- of DAPH compound. This leads to blue shift in bands of DAPH compound and disappearing of bands over 400nm (Table 2 and Figure 9). Bands below 300nm for DAPH and NBA imine compounds are assigned to $\pi-\pi^{*}$ transition and nearly didn't changed over altering of medium or its $\mathrm{pH}$.

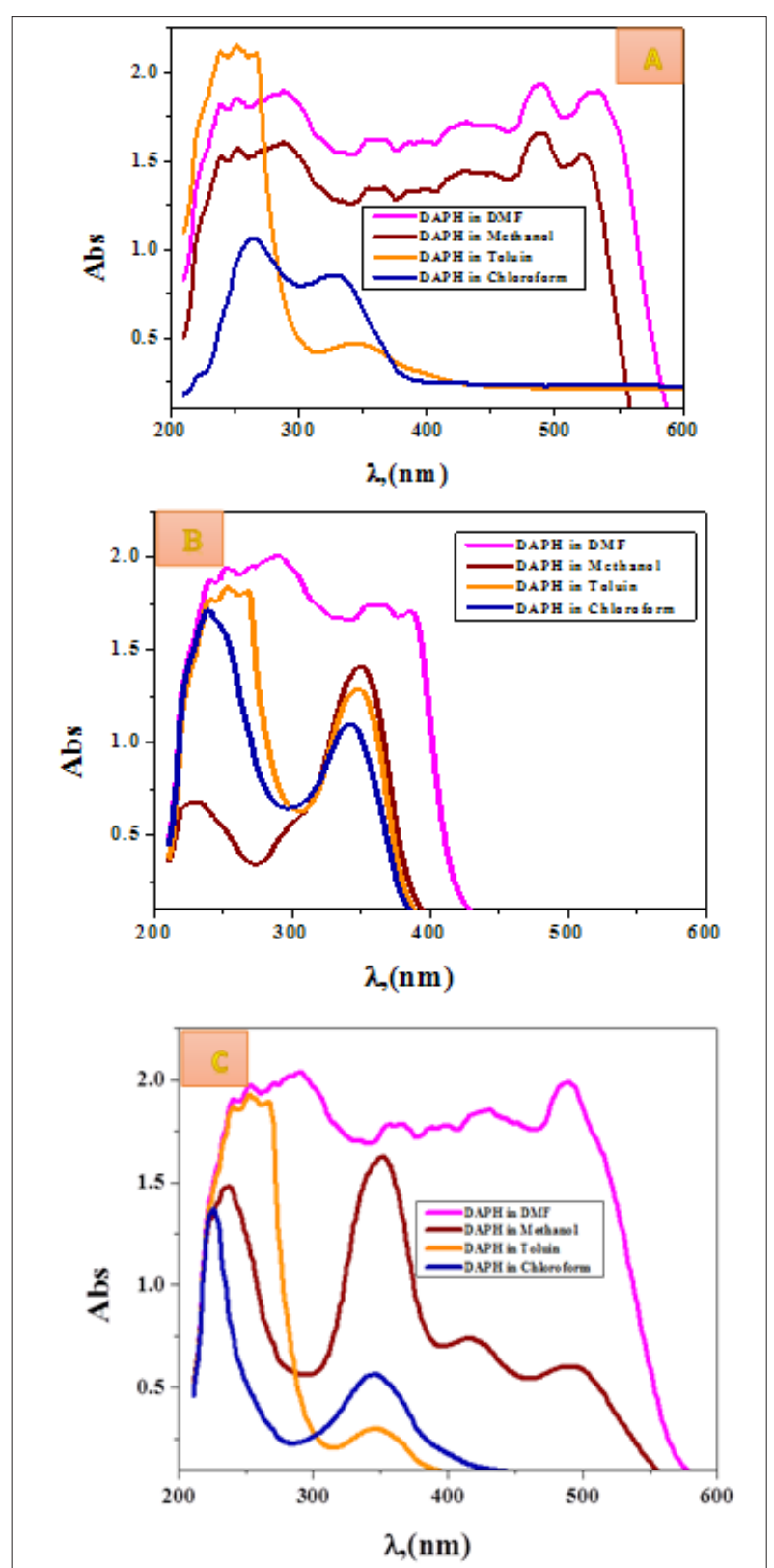

Figure 9: Molecular electronic spectra of DAPH imine in (A )various solvents (B) Basic medium (C) Acidic medium. 


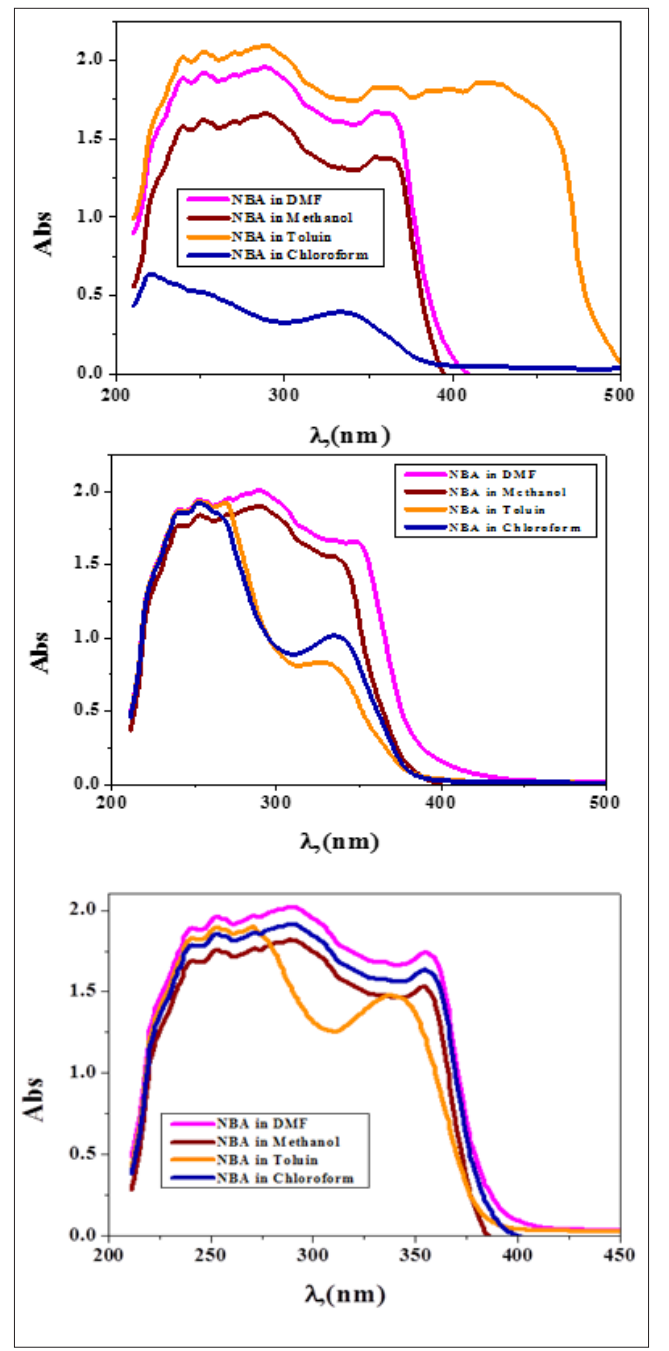

Figure 10: Molecular electronic spectra of NBA imine in (A) various solvents (B) Basic medium (C) Acidic medium.

Table 2: Absorption maxima $\left(\Lambda_{\max }\right)$ in various solvents, acidic and basic solutions.

\begin{tabular}{|c|c|c|c|c|c|c|}
\hline \multirow{3}{*}{ Solvent } & \multicolumn{3}{|c|}{ Compound } & \multicolumn{3}{|c|}{ Compound } \\
\hline & \multicolumn{3}{|c|}{ DHAP } & \multicolumn{3}{|c|}{ NBA } \\
\hline & Pure & Acidic & Basic & Pure & Acidic & Basic \\
\hline \multirow{7}{*}{ DMF } & 534.63 & - & - & 359.81 & 355.42 & 350.5 \\
\hline & 489.49 & 488.07 & - & 289.40 & 290.47 & 290.47 \\
\hline & 431.31 & 427.63 & 386.92 & 270.28 & 270.28 & 271.40 \\
\hline & 360.67 & 360.67 & 354.90 & 251.22 & 252.29 & 252.85 \\
\hline & 287.61 & 289.36 & 290.87 & 238.68 & 240.31 & 240.31 \\
\hline & 253.75 & 252.99 & 252.89 & & & \\
\hline & 237.70 & 239.21 & 239.21 & & & \\
\hline \multirow{8}{*}{ Methanol } & 521.50 & - & - & 360.38 & 353.79 & 336.87 \\
\hline & 489.49 & 491.66 & - & 289.97 & 290.47 & 289.97 \\
\hline & 430.55 & 417.43 & - & 269.78 & 270.85 & 270.85 \\
\hline & 360.00 & 351.97 & 350.47 & 251.22 & 252.85 & 252.89 \\
\hline & 289.36 & - & - & 238.68 & 240.31 & 239.75 \\
\hline & 251.58 & - & - & & & \\
\hline & 237.70 & 236.95 & - & & & \\
\hline & - & - & 229.68 & & & \\
\hline
\end{tabular}




\begin{tabular}{|c|c|c|c|c|c|c|}
\hline \multirow{4}{*}{ Chloroform } & 328.65 & 344.70 & 341.78 & 335.79 & 354.36 & 335.79 \\
\cline { 2 - 7 } & - & - & 239.21 & - & 289.97 & - \\
\cline { 2 - 7 } & 263.87 & - & - & 267 & 269.78 & 264 \\
\cline { 2 - 7 } & - & 226.08 & - & 251 & 252.29 & 252.54 \\
\hline \multirow{5}{*}{ Toluene } & 344.70 & 346.88 & 348.29 & 428.03 & -231 & 339.06 \\
\cline { 2 - 7 } & 266.79 & 268.97 & 268.29 & 360.88 & 270.85 & 269.78 \\
\cline { 2 - 7 } & 250.83 & 251.58 & 252.25 & 289.97 & 252.85 & 252.29 \\
\cline { 2 - 7 } & 238.45 & 239.21 & 239.87 & 251.72 & 239.75 & 239.75 \\
\hline
\end{tabular}

For NBA imine compound, on changing from a parotic solvent (methanol) to non protic solvent (DMF), it is observed that no changing in band of $n-\pi *$ This could be attributed to intramolecular hydrogen bond within the molecule are stable in methanol and DMF. In relatively less polar solvent (chloroform), a blue shift occurs for band of $n-\pi^{*}$ (Table 2 and Figure 10). A new band at 428nm appears for NBA compound in non-polar solvent (toluene) due to instability of intramolecular hydrogen bond within the molecule. On changing from neutral to acidic and basic medium, it is observed that a blue shift with band of $n-\pi^{*}$. This could be attributed to protonation of nitrogen atom of imine group in acidic medium and enhancement of resonance in the direction of electron withdrawn nitro group of NBA compound in basic medium (Figure 10).

\section{Sensing properties of the prepped imine compounds}

Visual color change: Optical examination of DMF solution $(0.1 \mathrm{mM})$ of receptor imine compounds had been investigated in presence of an aqueous solution $(0.1 \mathrm{mM})$ of different metal ions $\left(\mathrm{Cr}^{3+}, \mathrm{Fe}^{2+}, \mathrm{Vo}^{2+}, \mathrm{Co}^{2+}, \mathrm{Ni}^{2+}, \mathrm{Cu}^{2+}, \mathrm{Zn}^{2+}\right.$ and $\left.\mathrm{Pd}^{2+}\right)$ in $1: 1$ vol proportion. The color of DAPH and NBA are red and pale yellow in DMF $(0.1 \mathrm{mM})$ (Figure 11, 12); respectively. After addition of an aqueous solution of metal ions into the DMF solution of DAPH (Figure 11), a pale green color for $\mathrm{VO}^{2+}$, deep green color for $\mathrm{Co}^{2+}$, yellow color for $\mathrm{Cu}^{2+}$, orange color for $\mathrm{Fe}^{2+}$, green color for $\mathrm{Cr}^{3+}$, yellow-green for $\mathrm{Ni}^{2+}$, reddish brown color for $\mathrm{Pd}^{2+}$ and pale yellow for $\mathrm{Zn}^{2+}$ ions were formed. In case of NBA, after addition of an aqueous solution of metal ions to its aqueous solution (Figure 12), a pale green color for $\mathrm{VO}^{2+}$, blue color for $\mathrm{Co}^{2+}$, brown color for $\mathrm{Cu}^{2+}$, pale orange color for $\mathrm{Fe}^{2+}$, silver color for $\mathrm{Cr}^{3+}$, green color for $\mathrm{Ni}^{2+}$ and orange color for $\mathrm{Pd}^{2+}$ ions evolved that is simply detectable through naked eye. The results validated that DHAP shows excessive selectivity for all ions particularly $\mathrm{Co}^{2+}, \mathrm{Cu}^{2+}, \mathrm{Pd}^{2+}, \mathrm{Ni}^{2+}$ and $\mathrm{Zn}^{2+}$ ions in DMF-water blend. Also, the results demonstrated that NBA displays high selectivity for all ions particularly $\mathrm{Cu}^{2+}, \mathrm{Fe}^{2+}, \mathrm{Pd}^{2+}, \mathrm{Ni}^{2+}$ ions in DMF-water blend. It had been showed also that the color modification is most possibly due to the formation of a brand-new metal chelate, with unique electronic properties. The colorimetric adjustments had been investigated via observation over the time, as could be seen in Figure 13, the coloration of combinations containing receptor and metal ion have become frequently intense and light to the prepared imines after 4 days.

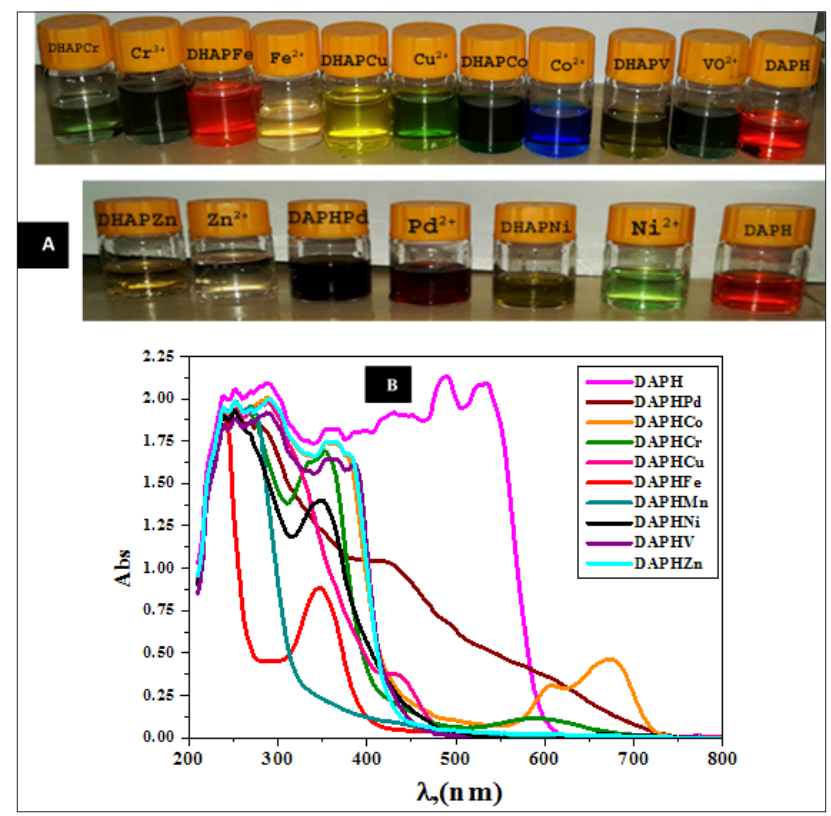

Figure 11: (A) color changes of interaction of $(0.1 \mathrm{mM})$ of DHAP imine ligand with $(0.1 \mathrm{mM})$ of the selected metal ions (B) UV-vis spectra of DAPH $(0.1 \mathrm{mM})$ in DMF after addition of 1.0 equivalent volume of various metal ions $(0.1 \mathrm{mM})$ in aqueous solution. 


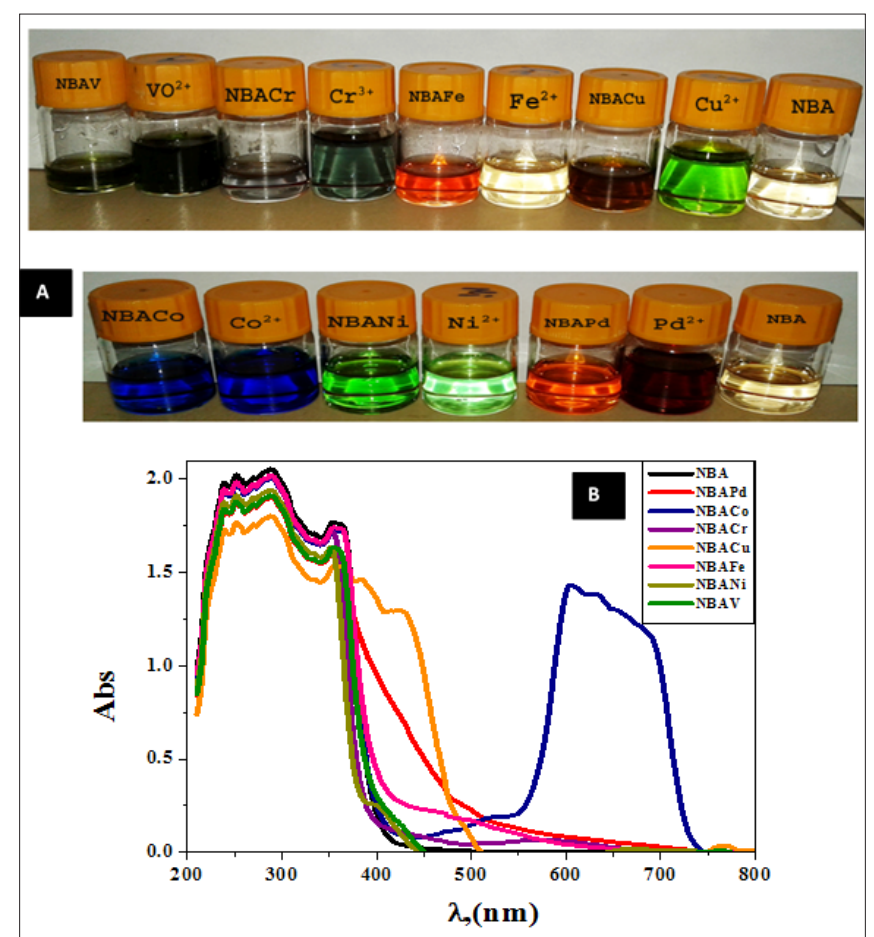

Figure 12: (A) color changes of interaction of $(0.1 \mathrm{mM})$ of NBA imine ligand with $(0.1 \mathrm{mM})$ of the selected metal ions (B) UV-vis spectra of NBA $(0.1 \mathrm{mM})$ in DMF after addition of 1.0 equivalent volume of various metal ions $(0.1 \mathrm{mM})$ in aqueous solution.

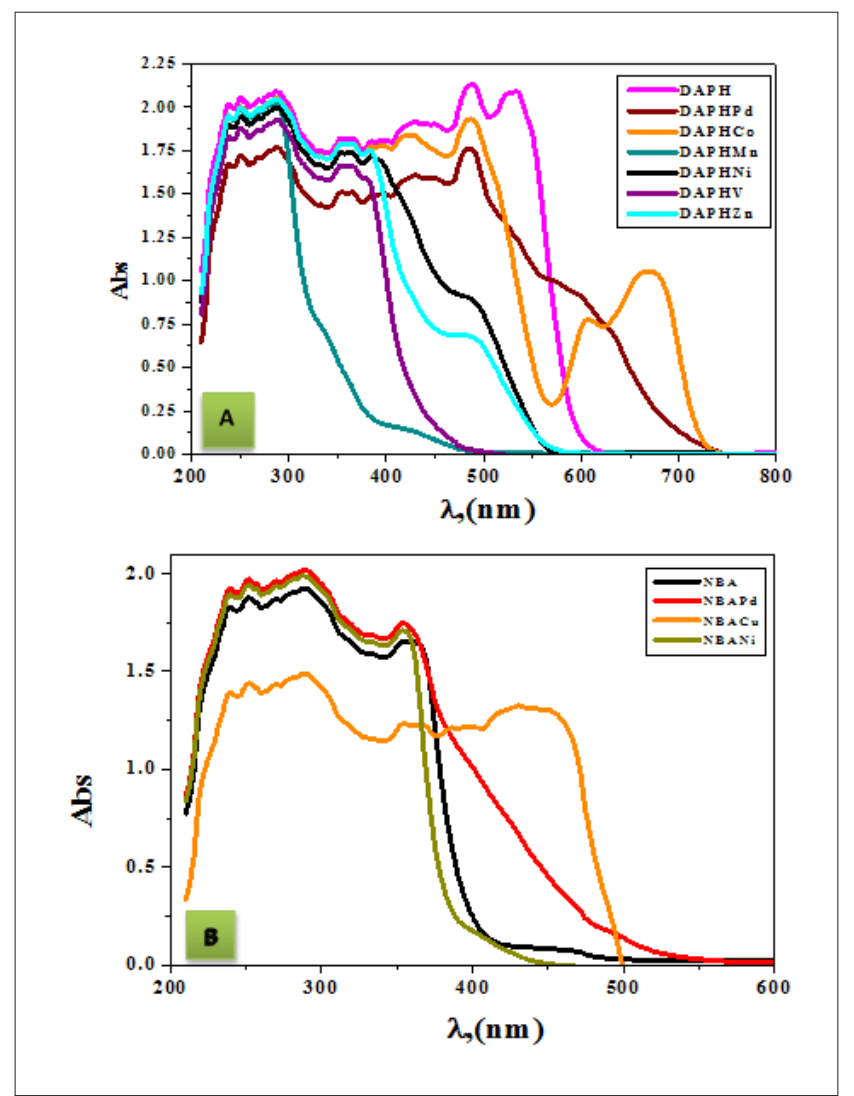

Figure 13: UV-vis spectra of (A) DAPH $(0.1 \mathrm{mM})$ and (B) NBA in DMF after addition of 1.0 equivalent volume of various metal ions $(0.1 \mathrm{mM})$ in aqueous solution, which recorded 4 days later. 
Sensitivity: The sensing properties of DHAP and NBA imines had been explored toward metal ions $\left(\mathrm{Cr}^{3+}, \mathrm{Fe}^{2+}, \mathrm{Vo}^{2+}, \mathrm{Co}^{2+}, \mathrm{Ni}^{2+}, \mathrm{Cu}^{2+}\right.$, $\mathrm{Zn}^{2+}$ and $\mathrm{Pd}^{2+}$ ) dissolved in water with the aid of UV-vis spectrum. In all cases, the mixing of DMF solution $(0.1 \mathrm{mM})$ of receptors with an aqueous solution $(0.1 \mathrm{mM})$ of metal ions had been at $1: 1 \mathrm{vol}$ ratio. Upon addition of various metal ions at 1 equivalent to DHAP imine receptor, the band of receptor at $534 \mathrm{~nm}$ red shifted $70 \mathrm{~nm}$ for $\mathrm{Co}^{2+}$ with appearing of new d-d transition bands at 604 and $670 \mathrm{~nm}$, red shifted $30 \mathrm{~nm}$ for $\mathrm{Pd}^{2+}$, red shifted $50 \mathrm{~nm}$ for $\mathrm{Cr}^{3+}$ and disappear for other selected metal ions $\left(\mathrm{Fe}^{2+}, \mathrm{Vo}^{2+}, \mathrm{Ni}^{2+}, \mathrm{Cu}^{2+}, \mathrm{Mn}^{2+}\right.$ and $\left.\mathrm{Zn}^{2+}\right)$. For a band at $489 \mathrm{~nm}$ of DHAP receptor, it occurs red shift by $6 \mathrm{~nm}$ for $\mathrm{Co}^{2+}$ and disappearing for other metal ions suggesting the coordination of ions with imine nitrogen (Figure 11). Under region of 400nm for DHAP receptor, there is no any notable change on addition to the selected metal ions. On addition of various metal ions at one equal to NBA receptor (Figure 12), there are a new bands were observed at 520,605 and $677 \mathrm{~nm}$ for $\mathrm{Co}^{2+}, 400 \mathrm{~nm}$ for $\mathrm{Ni}^{2+}, 385$ and $426 \mathrm{~nm}$ for $\mathrm{Cu}^{2+}$ and $467 \mathrm{~nm}$ for $\mathrm{Fe}^{2+}$ ions displaying strong interaction to NBA receptor with these metal ions.
Spectroscopic titration for the interaction of the investigated imine receptors with the selected metal ions: The cation binding properties of the prepared receptors had been studied via the absorption spectra all through titration of receptors in DMF with an aqueous solution of the selected metal ions. Upon addition of zero-ten equal volumes of $\mathrm{Co}^{2+}$ ion to a solution of DAHP receptor, new sturdy bands appeared at 605 and $670 \mathrm{~nm}$ (Figure 14). The band (360nm) of DAHP receptor moved to $355 \mathrm{~nm}$. However, no isosbestic point had been determined at some point of the titration. An increase in $\mathrm{Co}^{2+}$ volumes have been led to an increase in the absorbance of two main bands. Furthermore, for $\mathrm{Co}^{2+}$ ion quantity larger than ten equivalents, no considerable adjustments had been found inside the absorption spectrum. Beneath similar experimental condition, nearly the same behavior was observed for interaction of other selected metal ions with DAPH receptor (Figure 15-19). Addition, it is able to conclude that the absorbance of the bands of receptors had been decreased with the increasing $\mathrm{Pd}^{2+}$ ion volumes.

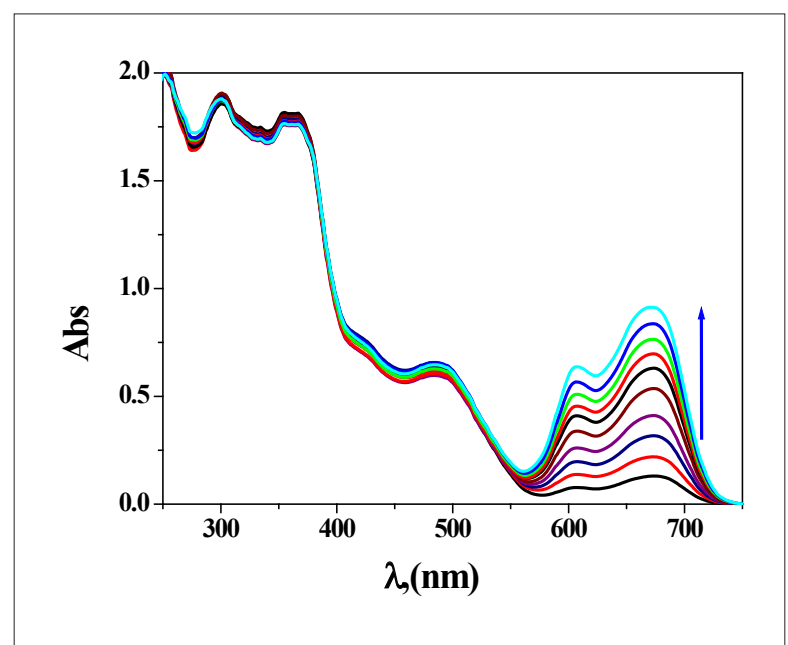

Figure 14: Spectrophotometric titration of DAPH $(0.1 \mathrm{mM})$ in DMF with various numbers of equivalent volume of $\mathrm{Co}(\mathrm{II})$ ion $(0.1 \mathrm{mM})$ in aqueous solution.

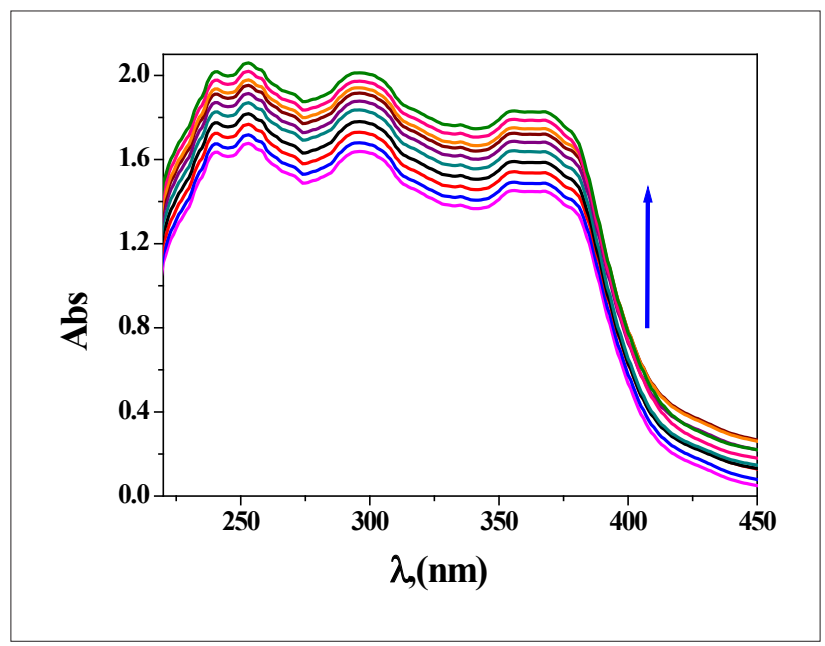

Figure 15: Spectrophotometric titration of DAPH $(0.1 \mathrm{mM})$ in DMF with various numbers of equivalent volume of $\mathrm{Ni}(\mathrm{II})$ ion $(0.1 \mathrm{mM})$ in aqueous solution. 


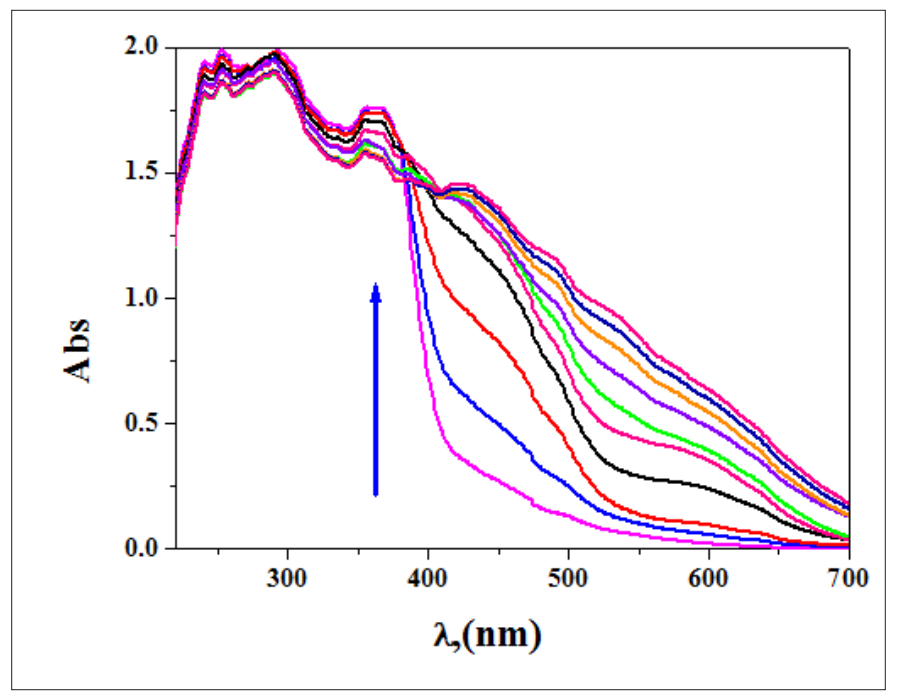

Figure 16: Spectrophotometric titration of DAPH $(0.1 \mathrm{mM})$ in DMF with various numbers of equivalent volume of $\mathrm{Pd}(\mathrm{II})$ ion $(0.1 \mathrm{mM})$ in aqueous solution.

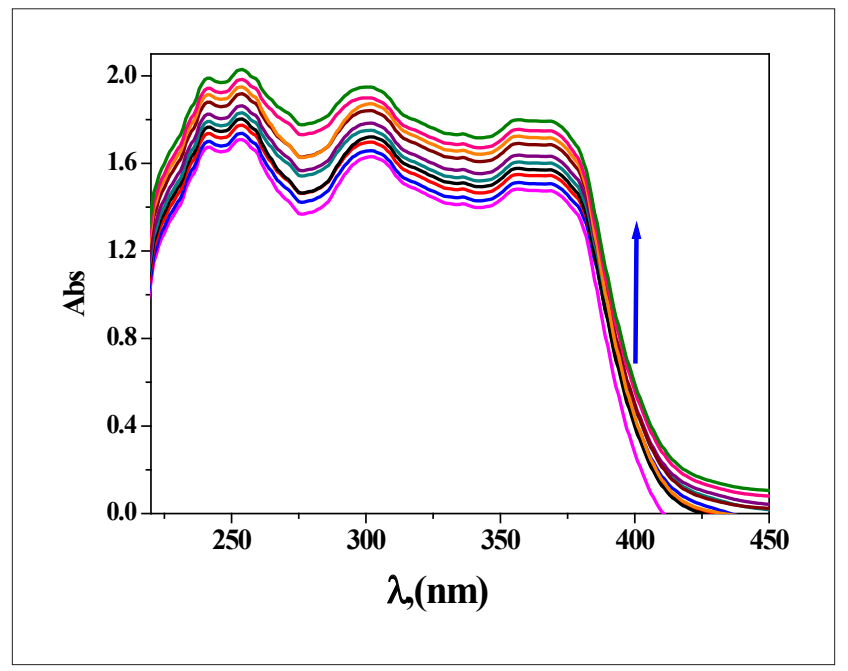

Figure 17: Spectrophotometric titration of DAPH $(0.1 \mathrm{mM})$ in DMF with various numbers of equivalent volume of $\mathrm{Mn}(\mathrm{II})$ ion $(0.1 \mathrm{mM})$ in aqueous solution.

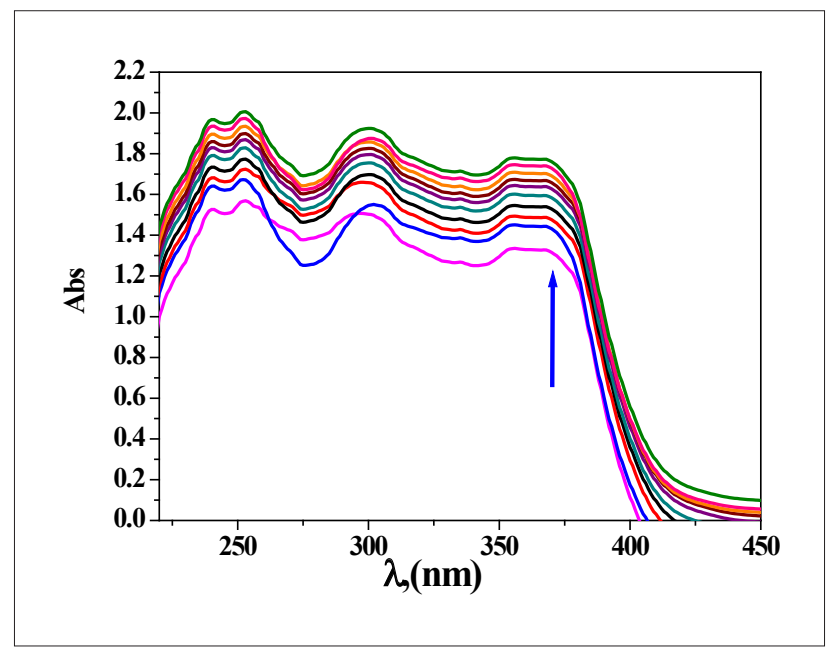

Figure 18: Spectrophotometric titration of DAPH $(0.1 \mathrm{mM})$ in DMF with various numbers of equivalent volume of $\mathrm{Zn}(\mathrm{II})$ ion $(0.1 \mathrm{mM})$ in aqueous solution. 


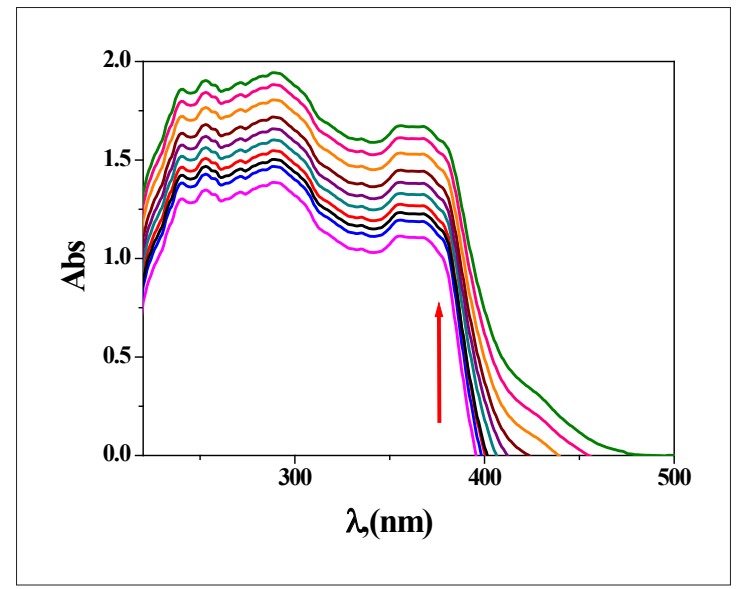

Figure 19: Spectrophotometric titration of DAPH $(0.1 \mathrm{mM})$ in DMF with various numbers of equivalent volume of $\mathrm{VO}(\mathrm{II})$ ion $(0.1 \mathrm{mM})$ in aqueous solution.

Upon addition of zero-ten equivalent volumes of $\mathrm{Cu}^{2+}$ ion to a solution of NBA receptor, new sturdy bands appeared at $435 \mathrm{~nm}$ (Figure 20) with observing of presence of isosbestic point throughout the titration. An increment in $\mathrm{Cu}^{2+}$ volumes had been led to an increase in the assimilation of this essential band.
Furthermore, for $\mathrm{Cu}^{2+}$ ion quantity large than ten equivalents, no considerable modification has been found inside the absorption spectrum. Underneath similar experimental condition, nearly the same behavior was observed for interaction of other selected metal ions with NBA receptor (Figure 21,22).

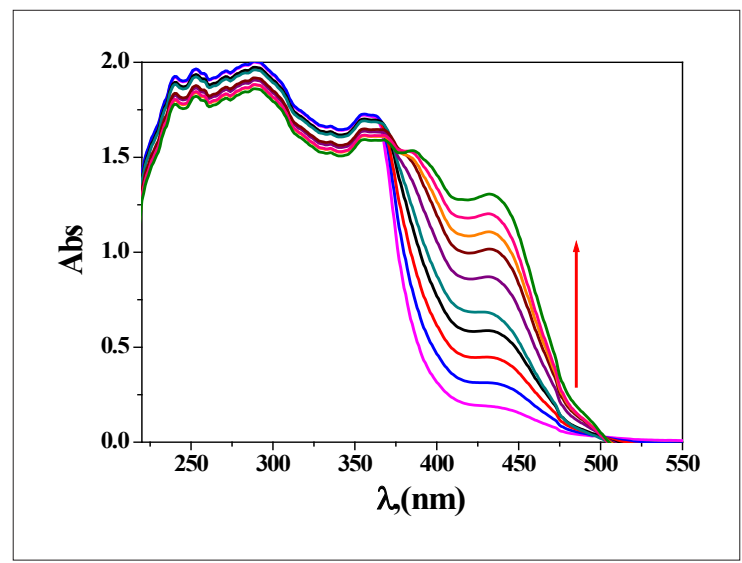

Figure 20: Spectrophotometric titration of NBA $(0.1 \mathrm{mM})$ in DMF with various numbers of equivalent volume of $\mathrm{Cu}(\mathrm{II})$ ion $(0.1 \mathrm{mM})$ in aqueous solution.

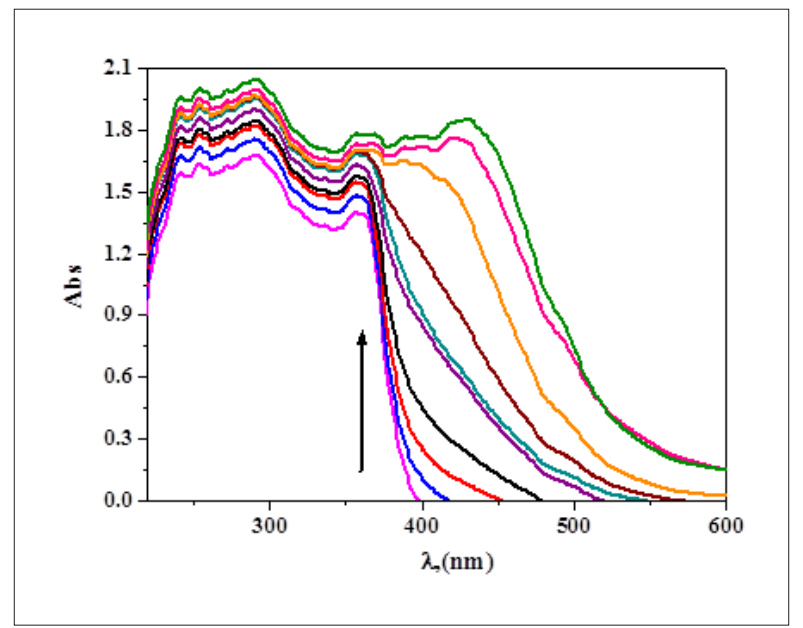

Figure 21: Spectrophotometric titration of NBA $(0.1 \mathrm{mM})$ in DMF with various numbers of equivalent volume of $\mathrm{Pd}(\mathrm{II})$ ion $(0.1 \mathrm{mM})$ in aqueous solution. 


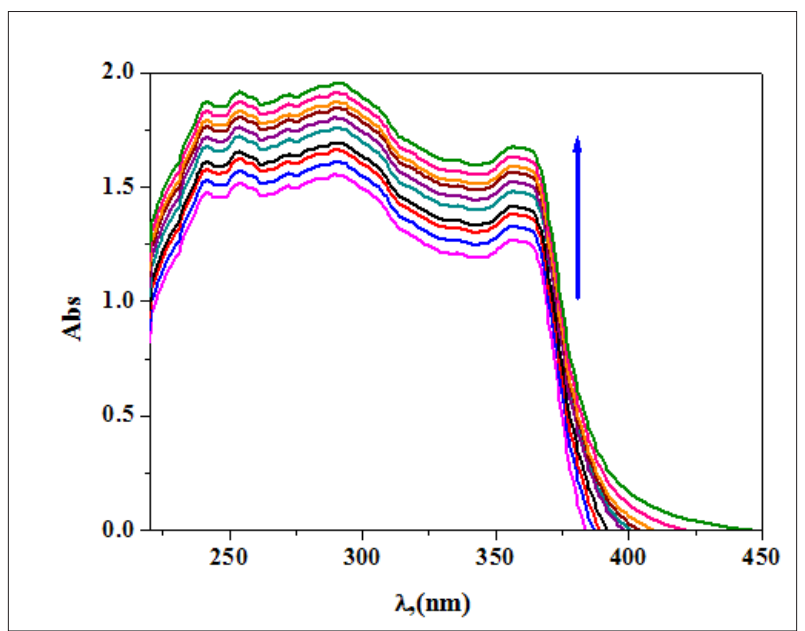

Figure 22: Spectrophotometric titration of NBA $(0.1 \mathrm{mM})$ in DMF with various numbers of equivalent volume of $\mathrm{Ni}(\mathrm{II})$ ion $(0.1 \mathrm{mM})$ in aqueous solution.

Stoichiometry: The complexation among the receptor and metal ion has been taken place following the given equilibrium

$$
a L+b M^{n+} \leftrightarrow(L a M b)^{b n+}
$$

Where $\mathrm{L}$ is ligand and $\mathrm{M}$ is metal ion, $\mathrm{a}$ and $\mathrm{b}$ are stoichiometry of ligand and metal ion, respectively and $\mathrm{n}$ is the charge on metal ion. Within the course of the complexation, the metal ion probably coordinates with the nitrogen atom of the azomethine group and the oxygen atom of hydroxyl group inside the NBA receptor and the two azomethine groups and nitrogen of pyridine ring in DAPH receptor. On the idea of this binding mode, the intramolecular charge transfer (ICT) process has been taken place throughout the complexation. Upon addition of the metal cation to receptor, red shift inside the absorption spectra may be determined because of this a more potent ICT from the electron donating hydroxyl group to the metal ion [42]. The red shift of $n-\pi^{*}$ transition band of azomethine group [43].

Utilizing of UV-vis titration, the stoichiometric ratio of the investigated chemo-sensors to metal ion inside the complex had been calculated. Whilst the plots of the lower in absorbance at $435 \mathrm{~nm}, 349 \mathrm{~nm}$ and $451 \mathrm{~nm}$ had been extrapolated, the ratio of Co(II), Pd(II) and Ni(II) got to nearly 1 respectively (Figure 23,24). Those outcomes had been indicated the 1:1 (L:M) stoichiometry for all the complexes. For NBA receptor, the red shift of $n-\pi^{*}$ transition band of azomethine group belong absorbance at $435 \mathrm{~nm}, 349 \mathrm{~nm}$ and $451 \mathrm{~nm}$ had been extrapolated, the ratio of Co(II), Pd(II) and Ni(II) got to nearly $0.75-1$ (Figure 25). That information had been showed the 1:1 (L:M) stoichiometry for all the complexes.

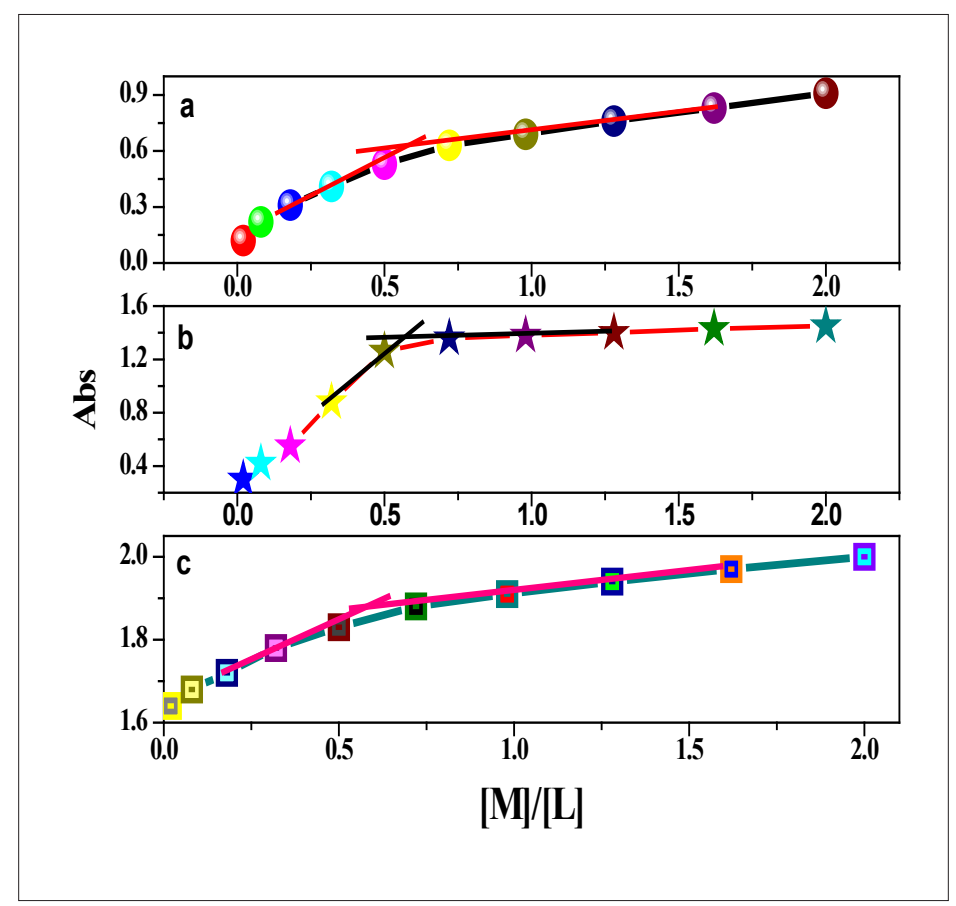

Figure 23: Plots of the UV-vis absorbance of DAPH at 671,431,296 nm with (a) Co(II), (b) Pd(II) and (c) Ni(II), respectively. 


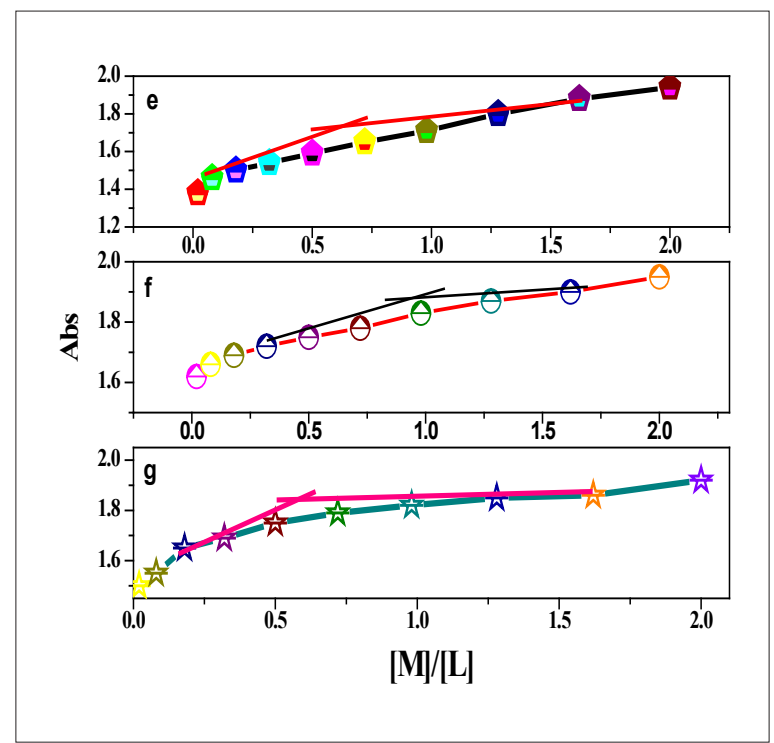

Figure 24: Plots of the UV-vis absorbance of DAPH at $368,369,369 \mathrm{~nm}$ with (e) VO(II), (f) $\mathrm{Mn}$ (II) and $\mathrm{Zn}$ (II), respectively.

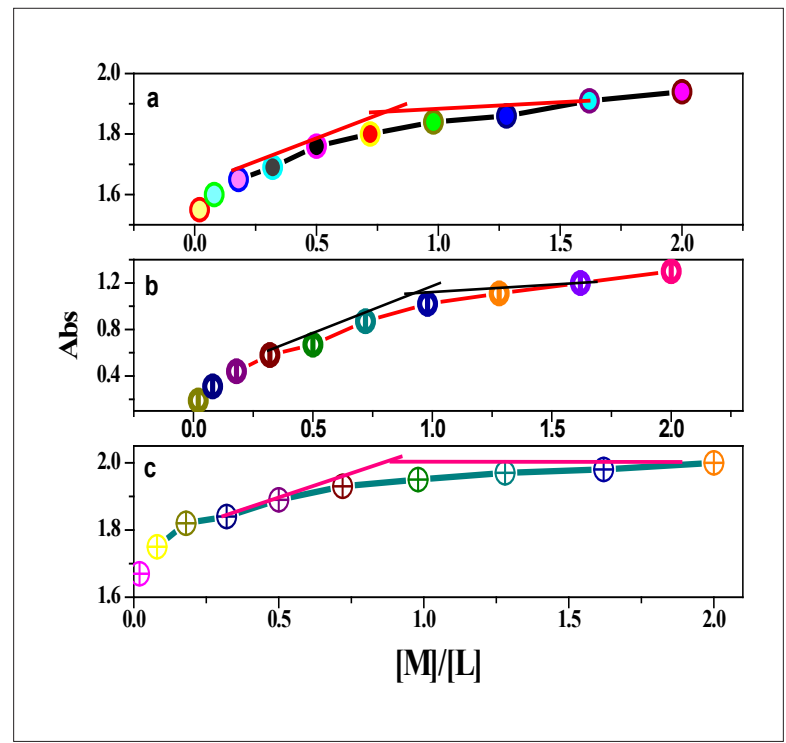

Figure 25: Plots of the UV-vis absorbance of NBA at $362,433,430$ nm with (a) Ni (II); b) Cu (II) and C) Pd (II), respectively.

Influence of time: It's miles recognized that imines go through hydrolysis in aqueous solution relying on time. Due to this, UV-vis spectra of all of the investigated receptors have been registered again after 4 days. It had been mentioned out that all receptors are stable for at the least four days in DMF-water blend. After 4 days, the absorption spectra for the interplay of receptors with metal ions had been confirmed no considerable alternate. It had been proved that the complexes which formed|are stable in time (Figure 15).

\section{Conclusion}

The condensation reaction of 3-nitro-benzaldyhide with 2-amino benzoic acid in molar ratio 1:1 afforded bi-dentate NBA imine receptor while condensation reaction between 2,6-diacetyl pyridine and phenyl hydrazine hydrochloride in molar ratio
1:2 afforded DAPH imine receptor. The elemental analyses and spectroscopic techniques such as NMR, IR and UV-visible spectra were used to the characterization of all the prepared imine chemosensors. DFT calculation was performed to confirm the structure of the prepared compounds. Moreover, molecular electronic spectra for the prepared imines were checked in solvents of different polarities at different $\mathrm{pH}$ media. In addition to, optical examination of DMF solution $(0.1 \mathrm{mM})$ of receptor imine compounds had been checked in presence of an aqueous solution $(0.1 \mathrm{mM})$ of several metal ions $\left(\mathrm{Cr}^{3+}, \mathrm{Fe}^{2+}, \mathrm{Vo}^{2+}, \mathrm{Co}^{2+}, \mathrm{Ni}^{2+}, \mathrm{Cu}^{2+}, \mathrm{Zn}^{2+}\right.$ and $\left.\mathrm{Pd}^{2+}\right)$ in one: one vol ratio to check their sensing properties. The color alteration in receptor DAPH extension metal ions showed deep green color for $\mathrm{Co}^{2+}$, yellow color for $\mathrm{Cu}^{2+}$, orange color for $\mathrm{Fe}^{2+}$, green color for $\mathrm{Cr}^{3+}$ , yellow-green for $\mathrm{Ni}^{2+}$, reddish brown color for $\mathrm{Pd}^{2+}$ and pale yellow 
for $\mathrm{Zn}^{2+}$ ions were formed which have been visible to naked eye. Results had been demonstrated that DHAP has been displayed high selectivity for all ions especially $\mathrm{Co}^{2+}, \mathrm{Cu}^{2+}, \mathrm{Pd}^{2+}, \mathrm{N}^{\mathrm{i2+}}$ and $\mathrm{Zn}^{2+}$ ions in DMF-water blend. Alternatively, upon addition of metal ions to NBA receptor showed a blue color for $\mathrm{Co}^{2+}$, brown color for $\mathrm{Cu}^{2+}$, pale orange color for $\mathrm{Fe}^{2+}$, silver color for $\mathrm{Cr}^{3+}$, green color for $\mathrm{Ni}^{2+}$ and orange color for $\mathrm{Pd}^{2+}$ ions evolved that's absolutely detectable by using naked eye which imply that NBA has showed high selectivity for all ions especially $\mathrm{Cu}^{2+}, \mathrm{Fe}^{2+}, \mathrm{Pd}^{2+}, \mathrm{Ni}^{2+}$ ions in DMF-water mixture.

\section{References}

1. Hariharan PS, Anthony SP (2015) Substitutional group dependent colori/fluorimetric sensing of $\mathrm{Mn} 2+, \mathrm{Fe} 3+$ and $\mathrm{Zn} 2+$ ions by simple Schiff base chemosensor. Spectrochim Acta A 136: 1658-1665.

2. You GR, Park GJ, Lee SA, Ryu KY, Kim C (2015) Chelate-type Schiff base acting as a colorimetric sensor for iron in aqueous solution. Sens Actuators B 215: 188-195.

3. Gupta VK, Singh AK, Mehtab S, Gupta B (2006) A cobalt(II)-selective PVC membrane based on a Schiff base complex of N,N'-bis(salicylidene)-3,4diaminotoluene. Anal Chim Acta 566(1): 5-10.

4. Peralta Domínguez D, Rodríguez M, Ramos Ortíz G, Maldonado J L, Meneses-Nava M A, et al. (2015) A Schiff base derivative from cinnamaldehyde for colorimetric detection of $\mathrm{Ni}^{2+}$ in water. Sens Actuators B 207: 511-517.

5. Zhou L, Cai P, Feng Y, Cheng J, Xiang H, et al. (2012) Synthesis and photophysical properties of water-soluble sulfonato-Salen-type Schiff bases and their applications of fluorescence sensors for $\mathrm{Cu}^{2+}$ in water and living cells. Anal Chim Acta 735: 96-106.

6. Huerta-Aguilar CA, Pandiyan T, Singh N, Jayanthi N (2015) Three novel input logic gates supported by fluorescence studies: Organic nanoparticles (ONPs) as chemo-sensor for detection of $\mathrm{Zn}^{2+}$ and $\mathrm{Al}^{3+}$ in aqueous medium. Spectrochim Acta A 146: 142-150.

7. Abdel Aziz AA, Seda SH (2014) Detection of trace amounts of $\mathrm{Hg}^{2+}$ in different real samples based on immobilization of novel unsymmetrical tetradentate Schiff base within PVC membrane. Sens Actuators B 197: 155-163.

8. Qin JC, Yang ZY (2015) Bis-Schiff base as a donor-acceptor fluorescent probe: Recognition of $\mathrm{Al}^{3+}$ ions in near $100 \%$ aqueous solution. J Photochem Photobiol A 303-304: 99-104.

9. Kocak N, Sahin M, Kücükkolbasi S, Ozden Erdogan Z (2012) Synthesis and characterization of novel nano-chitosan Schiff base and use of lead (II) sensor. Int J Biol Macromol 51(5): 1159-1166.

10. Abu Dief AM, Díaz Torres R, Sañudo EC, Abdel Rahman LH, Alcalde NA (2013) Novel sandwich triple-decker di-nuclear Nd III-(bis-N,N' -pbromo-salicylideneamine-1,2-diaminobenzene) complex. Polyhedron 64: 203-208.

11. Abdel Rahman LH, El Khatib RM, Nassr LAE, Abu Dief AM (2013) Synthesis, physicochemical studies, embryos toxicity and DNA interaction of some new Iron (II) Schiff base amino acid complexes. J Mole Struct 1040: 9-18.

12. Abdel Rahman LH, El Khatib RM, Nassr LAE, Abu Dief AM, Ismael M, et al. (2014) Metal based pharmacologically active agents: Synthesis, structural characterization, molecular modeling, CT-DNA binding studies and in vitro antimicrobial screening of iron(II) bromosalicylidene amino acid chelates. Spectrochim Acta A Mol Biomol Spectrosc 117: 366-378.

13. Abdel Rahman LH, Abu Dief AM, Hashem NA, Seleem AA (2015) Recent advances in synthesis, characterization and biological activity of nano sized Schiff base amino acid M(II) complexes. Int J Nano Chem 1(2): 7995.
14. Abu Dief AM, Nassr LAE (2015) Tailoring, physicochemical characterization, antibacterial and DNA binding mode studies of $\mathrm{Cu}(\mathrm{II})$ Schiff bases amino acid bioactive agents incorporating 5-bromo-2-hydroxybenzaldehyde. J Iran Chem Soc 12(6): 943-955.

15. Abdel Rahman LH, Abu Dief AM, Ismael M, Mohamed A A, Hashem NA (2016) Synthesis, structure elucidation, biological screening, molecular modeling and DNA binding of some $\mathrm{Cu}(\mathrm{II})$ chelates incorporating imines derived from amino acids. J Mol Struct 1103: 232-244.

16. Abdel Rahman LH, Abu Dief AM, El Khatib RM, Abdel Fatah SM (2016) Some new nano-sized Fe(II), Cd(II) and Zn(II) Schiff base complexes as precursor for metal oxides: Sonochemical synthesis, characterization, DNA interaction, in vitro antimicrobial and anticancer activities. Bioorg Chem 69: 140-152.

17. Abdel Rahman LH, Ismail NM, Ismael M, Abu Dief AM, Ahmed EA (2017) Synthesis, characterization, DFT calculations and biological studies of $\mathrm{Mn}(\mathrm{II}), \mathrm{Fe}(\mathrm{II}), \mathrm{Co}(\mathrm{II})$ and $\mathrm{Cd}(\mathrm{II})$ complexes based on a tetradentate ONNO donor Schiff base ligand. J Mol Struct 1134: 851-862.

18. Abdel Rahman LH, Abu Dief AM, Mostafa H, Hamdan SK (2017) Ni(II) and $\mathrm{Cu}(\mathrm{II})$ complexes with ONNO asymmetric tetradentate Schiff base ligand: synthesis, spectroscopic characterization, theoretical calculations, DNA interaction and antimicrobial studies. Appl Organomet Chem 31(2): e3555.

19. Yilmaz I, Temel H, Alp H (2008) Synthesis, electrochemistry and in situ spectro electrochemistry of a new Co(III) thio Schiff-base complex with $\mathrm{N}, \mathrm{N}^{\prime}$-bis(2-aminothiophenol)-1,4-bis (carboxylidene phenoxy)butane. Polyhedron 27: 125-132.

20. Ando R, Ono H, Yagyu T, Maeda M (2004) Spectroscopic characterization of mononuclear, binuclear, and insoluble polynuclear oxovanadium (IV)-Schiff base complexes and their oxidation catalysis. Inorg Chim Acta 357(3): 817-823.

21. Abdel Rahman LH, Abu Dief AM, Adam MSS, Hamdan SK (2016) Some new nano-sized mononuclear $\mathrm{Cu}(\mathrm{II})$ schiff base complexes: Design, characterization, molecular modeling and catalytic potentials in benzyl alcohol oxidation. Catal Lett 146(8): 1373-1396.

22. Dai B, Cao M, Fang G, Liu B, Dong X, et al. (2012) Schiff base-chitosan grafted multiwalled carbon nanotubes as a novel solid-phase extraction adsorbent for determination of heavy metal by ICP-MS. J Hazard Mater 219-220: 103-110.

23. Chen Y, Liu Y, Zhang X, Zhang Z, Liu L, et al. (2015) Stereo-regulated methyl methacrylate (MMA) polymerization catalyzed by asymmetric Salen-type Schiff-base Cu(II) complexes. Inorg Chem Commun 53: 1-3.

24. Abdel Rahman LH, Abu Dief AM, El Khatib RM, Abdel Fatah SM (2016) Sonochemical synthesis, DNA binding, antimicrobial evaluation and in vitro anticancer activity of three new nano-sized $\mathrm{Cu}(\mathrm{II}), \mathrm{Co}(\mathrm{II})$ and $\mathrm{Ni}(\mathrm{II})$ chelates based on tri-dentate NOO imine ligands as precursors for metal oxides. J Photochem Photobiol B 162: 298-308.

25. Abdel Rahman LH, Abu Dief AM, Hamdan SK, Seleem AA (2015) Nano Structure Iron (II) and Copper (II) Schiff Base Complexes of a NNOTridentate Ligand as New Antibiotic Agents: Spectral, Thermal Behaviors and DNA Binding Ability. Int J Nano Chem 1: 65-77.

26. Khanye SD, Gutb J, Rosenthal PJ, Chibale K, Smith GS (2011) Ferrocenylthiosemicarbazones conjugated to a poly(propyleneimine) dendrimer scaffold: Synthesis and in vitro antimalarial activity. J Organomet Chem 696(21): 3296-3300.

27. Kraicheva I, Tsacheva I, Vodenicharova E, Tashev E, Tosheva T, et al. (2012) Synthesis, antiproliferative activity and genotoxicity of novel anthracene-containing aminophosphonates and a new anthracenederived Schiff base. Bioorg Med Chem 20(1): 117-124.

28. Alafeefy AM, Bakht MA, Ganaie MA, Ansarie MN, El Sayed NN, et al. (2015) Synthesis, analgesic, anti-inflammatory and anti-ulcerogenic activities of certain novel Schiff's bases as fenamate isosteres. Bioorg Med Chem Lett 25(2): 179-183. 
29. Kumar KS, Ganguly S, Veerasamy R, De Clercq E (2010) Synthesis, antiviral activity and cytotoxicity evaluation of Schiff bases of some 2-phenyl quinazoline-4(3)H-ones. Eur J Med Chem 45(11): 5474-5479.

30. Abdel Rahman LH, Abu Dief AM, Aboelez MO, Hassan Abdel Mawgoud AA (2017) DNA interaction, antimicrobial, anticancer activities and molecular docking study of some new VO(II), Cr(III), Mn(II) and Ni(II) mononuclear chelates encompassing quaridentate imine ligand. J Photochem Photobiol B 170: 271-285.

31. Abdel Rahman LH, Abu Dief AM, Basha M, Abdel Mawgoud AAH (2017) Three novel Ni(II), VO(II) and Cr(III) mononuclear complexes encompassing potentially tridentate imine ligand: Synthesis, structural characterization, DNA interaction, antimicrobial evaluation and anticancer activity. Appl Organometal Chem 31(11): e3750.

32. Abdel Rahman LH, Abu Dief AM, Newair EF, Hamdan SK (2016) Some new nano-sized $\mathrm{Cr}(\mathrm{III}), \mathrm{Fe}(\mathrm{II}), \mathrm{Co}(\mathrm{II})$, and $\mathrm{Ni}(\mathrm{II})$ complexes incorporating 2-((E)-(pyridine-2-ylimino)methyl)napthalen-1-olligand: Structural characterization, electrochemical, antioxidant, antimicrobial, antiviral assessment and DNA interaction. J Photochem Photobiol B 160: 18-31.

33. Abd El-Lateef HM, Abu Dief AM, Moniur AA (2017) Corrosion inhibition of carbon steel pipelines by some novel Schiff base compounds during acidizing treatment of oil wells studied by electrochemical and quantum chemical methods. J Mol Struc 1130: 522-542.

34. Al Zoubi W and Al Mohanna N D (2014) Membrane sensors based on Schiff bases as chelating ionophores-A review. Spectrochim Acta A 132: 854-870.

35. Abdel Aziz AA (2013) A novel highly sensitive and selective optical sensor based on a symmetric tetradentate Schiff-base embedded in PVC polymeric film for determination of $\mathrm{Zn}^{2+}$ ion in real samples. J Lumin 143: 663-669.

36. Hosny NM, Hussien MA, Radwana FM, Nawar N (2014) Synthesis, spectral characterization and DNA binding of Schiff-base metal complexes derived from 2-amino-3-hydroxyprobanoic acid and acetylacetone. Spectrochim Acta A 132: 121-129.
37. Abdel-Rahman LH, Abu-Dief AM, El-Khatib RM, Abdel-Fatah SM (2018) Sonochemical synthesis, spectroscopic characterization, 3d molecular modeling, DNA binding and antimicrobial evaluation of some transition metal complexes based on bidentate no donor imine ligand. Int J Nano Chem 4(1): 1-17.

38. Abdel-Rahman LH, El-Khatib RM, Nassr LAE, Abu-Dief AM, Lashin FE (2013) Design, characterization, teratogenicity testing, antibacterial, antifungal and DNA interaction of few high spin Fe(II) Schiff base amino acid complexes. Spectrochim Acta Part A Mol Biomol Spectrosc 111: 266-276.

39. Ibrahim EMM, Abdel Rahman LH, Abu-Dief AM, El-Khatib RM, AbdelFatah SM, et al. (2018) Sonochemical synthesis, structural inspection and semiconductor behavior of three new nano sized $\mathrm{Cu}$ (II), Co(II) and $\mathrm{Ni}(\mathrm{II})$ chelates based on tri-dentate NOO imine ligand as precursors for metal oxides. Appl Organometal Chem 32(3): e4171.

40. Abdel-Rahman LH, Abu-Dief AM, Shehata MR, Atlam FM, AbdelMawgoud AAH (2019) Some new Ag(I), VO(II) and Pd(II) chelates incorporating tridentate imine ligand: Design, synthesis, structure elucidation, density functional theory calculations for DNA interaction, antimicrobial and anticancer activities and molecular docking studies. Appl Organometal Chem 33(4): e4699.

41. Abdel-Rahman LH, Abu-Dief AM, Abdel-Mawgoud AAH (2019) Development, structural investigation, DNA binding, antimicrobial screening and anticancer activities of two novel quari-dentate VO(II) and Mn (II) mononuclear complexes. J King Saud Uni 31(1): 52-60.

42. Mergu N and Gupta VKK (2015) A novel colorimetric detection probe for copper (II) ions based on a Schiff base. Sens Actuators B 210: 408-417.

43. Hariharan PS, Anthony SP (2015) Substitutional group dependent colori/fluorimetric sensing of $\mathrm{Mn} 2+, \mathrm{Fe} 3+$ and $\mathrm{Zn} 2+$ ions by simple Schiff base chemosensor. Spectrochim Acta A 136: 1658-1665. 